\title{
Factors Affecting Harmony among Law Enforcement Agencies in Indonesia
}

\author{
Zahratul Idami* \\ DOI: https://doi.org/10.22304/pjih.v5n1.a9
}

Submitted: November 28, 2017 | Accepted: May 2, 2018

\begin{abstract}
Harmonization among law enforcement agency is necessary in order to achieve the objectives of law, namely to achieve justice, legal certainty and law usefulness. In reality, the harmony among legal institutions is difficult to be implemented. There are many misconducts of law enforcement processes, such as mafia in judiciary, discriminatory courts, and misconduct of judicial processes. This paper will elaborate the influencing factors of harmonization among law enforcement agencies in order to improve the quality of law enforcement activities as well as the efforts to handle the problems emerged. The result of this research indicates that there are several factors affecting harmonization among law enforcement agencies in Indonesia; (a) laws or regulations; (b) law enforcement agencies and law enforcement; (c) community; and (d) culture. There are some efforts taken to optimize the various regulations, both at the central and regional levels. Thus, the harmonization can be implemented in accordance with existing rules and regulations. In carrying out their duties and functions, law enforcement agencies must be well-coordinated and their duties are clear so that there is no inter-institutional intervention that leads to unfair judicial practices or misappropriations. There should be training and strengthening of each law enforcement agency to create a same vision and mission in achieving legal objectives and supporting law enforcement. There should be a socialization also to the society concerning the process of justice to avoid peoples break the rules, violating ethics, and having lack of understanding on due process of law. Legal education must be initiated in early stage to build people awareness on law, to create a positive culture, and to enhance respect to the law. It is expected that the objectives of the law and the goals of the state can be fulfilled.
\end{abstract}

Keywords: harmonization of institution, law institution, law enforcement.

\section{Faktor yang Mempengaruhi Harmonisasi antar Lembaga Penegak Hukum dalam Penegakan Hukum di Indonesia}

\begin{abstract}
Abstrak
Harmonisasi antara lembaga penegak hukum perlu dilakukan guna tercapainya tujuan hukum yaitu mencapai keadilan, kepastian dan kemanfaatan. Dalam kenyataannya harmonisasi antar lembaga hukum ini sulit dilakukan, hal ini dibuktikan dengan banyaknya praktik penyelewengan dalam proses penegakan hukum seperti, mafia hukum di peradilan, peradilan yang diskriminatif atau rekayasa proses peradilan. Tulisan ini bertujuan untuk menjelaskan faktor yang mempengaruhi harmonisasi antar lembaga penegak hukum dalam penegakan hukum dan upaya yang dilakukan untuk mengatasinya. Hasil kajian ini menunjukkan bahwa Faktor yang mempengaruhi harmonisasi antar lembaga penegak hukum di Indonesia adalah: (a) faktor hukumnya sendiri atau regulasinya; (b) faktor lembaga penegak hukum dan faktor penegak hukum; (c) faktor masyarakat; (d) faktor kebudayaan. Upaya yang

PADJADJARAN Journal of Law Volume 5 Number 1 Year 2018 [ISSN 2460-1543] [e-ISSN 2442-9325]

Lecturer of Constitutional Law, Faculty of Law, Universitas Syiah Kuala Darussalam Banda Aceh, zahratulidami_ isa@unsyiah.ac.id, S.H., M.Hum., Dr. (Universitas Syiah Kuala).
\end{abstract}


dapat dilakukan adalah mengupayakan berbagai peraturan baik yang berasal dari pusat maupun daerah, sehingga harmonisasi bisa diwujudkan sesuai dengan aturan yang ada. Tugas dan fungsi Lembaga penegak hukum harus ada koordinasi dan jelas sehingga tidak terjadi intervensi antar lembaga yang menyebabkan terjadi praktek peradilan yang tidak adil atau penyelewengan. Hendaknya ada pelatihan dan penguatan masing-masing penegak hukum sehingga antara sesama mereka sama visi dan misi untuk mencapai tujuan hukum dan mendukung penegakan hukum. Masyarakat harus diberi sosialisasi dalam mencari keadilan karena sering masyarakat yang melanggar etika dan kurang memahami proses hukum yang telah ditentukan. Pendidikan hukum harus dimulai sejak dini agar kesadaran hukum masyarakat menjadi budaya dan membentuk masyarakat yang menghargai hukum, sehingga tujuan hukum dan tujuan negara akan terwujud.

Kata kunci: harmonisasi institusi, lembaga hukum, penegakan hukum.

\section{A. Introduction}

Conceptually, the core and the meaning of law enforcement covers activities to harmonize values that are outlined in embodied norms and acts of conduct as a series of end-stage value descriptions to create, maintain, and defending peace of life. ${ }^{1}$ Social interaction is preserved if all parties can maintain, and not harm or violate, the rights of anyone. If a person does not maintain, and violates the rights of others, then, in a legal state, that person will be prosecuted under the law. ${ }^{2}$

The position of law as a supreme order in a state does not just happens. Through a long process, people around the world agree to place law as a written guide that must be obeyed to maintain order, security, and justice. Nevertheless, in the implementation process, there are various problems so that law cannot be enforced easily. Law enforcement in Indonesia is carried out by several institutions. They are the police, the Prosecutor's Office, the judiciary, and the penitentiary. The law enforcement officials include police, attorneys, judges, and lawyers. Each of these law enforcement officials and agencies must be in harmony in enforcing the law so that the objectives of the law can be achieved.

Currently, people are no longer afraid of the threat of punishment, as long as there is a strong backing from law enforcement officials. This fact is one of the bad indicators of law enforcement in this state. Nowadays, people have become highly trained to avoid lawsuits. Law enforcement issues have always been an interesting issue, mainly because of the imbalance between the public compliance with the law and the dynamic interaction between the legal aspect of hope or Das Sollen and the application of law in reality or Das Sein. ${ }^{3}$

The level of public confidence in law and law enforcement officials is very low. Especially with the increasing number of news in the mass media that describes the deviant behavior of law enforcement officials, so law enforcement agencies

Soerjono Soekanto, Faktor-Faktor yang Mempengaruhi Penegakan Hukum, Jakarta: Rajawali Pers, 2014, p. 5. Ibid.

Rif'ah Roihanah, "Penegakan Hukum di Indonesia: Harapan dan Kenyataan”, Justitia Islamica, Vol. 12, No. 1, 2015, p. 40. 
are currently in an unfavorable position. In corruption cases, for example, law enforcement agencies such as the Corruption Eradication Commission (KPK), the Indonesian National Police (Polri), and the Prosecutor's Office must synergize with regulated norms so as not to impose and discredit each other.

Based on the above description, this study is to answer the questions about the factors affecting harmony among law enforcement institutions in law enforcement activities and the efforts to overcome these factors. This study was conducted with the aim of reviewing and explaining the factors affecting harmony among law enforcement agencies; and reviewing and explaining possible efforts to address the factors affecting the harmony.

\section{B. Definition of Harmony, Law Enforcement Agencies, and Law Enforcement Officials}

In the Cambridge English Dictionary, the word 'harmony' means a situation in which people are peaceful and agree with each other, or when things seem right or suitable together. ${ }^{4}$ In this case, the meaning of harmony in this paper is the effort of the law enforcement agencies to achieve legal objectives and the purpose of the state. The process to achieve a harmony is called harmonization. Harmonization in a narrow sense means joint effort to equate views, judgments, or action steps in order to achieve common goals or targets. Since it is a form of joint effort, there are many parties involved in achieving the common goals or targets.

According to the Preamble of the 1945 Constitution of the Republic of Indonesia (the 1945 Constitution), the purpose of the state is to protect the entire nation of Indonesia and its citizen, promote the general welfare, educate the life of the nation, and participating in realization of the world order based on eternal peace and social justice. Furthermore, Article 1(3) of the 1945 Constitution states that "the state of Indonesia is based on rule of law". The law is also the supremacy. Therefore, law enforcement is one of the roads leading to the realization of rule of law because a feature of a state based on rule of law is independent and impartial judiciary.

If all law enforcement agencies are in harmony, it will be easy to implement the goals of the state and the objectives of law. Harmony is the most needed aspect in realizing the goals because it is a basic capital of the law enforcement. In order to make all institutions support each other in achieving the goals of the state, then the harmony must be realized-for example, the harmony among prosecutor's offices, police, judicial institutions, and attorneys.

Law must be closely intertwined with justice since law is a fair regulation. If a law is contrary to the principles of justice, then the law is not normative anymore and cannot be regarded as law. It is due to the fact that the ultimate goal of law is justice. Therefore, all efforts related to the law enforcement must absolutely be directed to find a legal system that is most suitable and in accordance with the principles of Cambridge English Dictionary, 'harmony', https://dictionary.cambridge.org/dictionary/english/harmony,
accessed on September 2017. 
justice. A law only becomes real law when it meets the principles of justice. In other words, justice is a constitutive element of all definition of law. ${ }^{5}$

According to Jimly Asshidiqie, law enforcement is a process of conducting efforts for the establishment or functioning of legal norms in real terms as a code of conduct in legal traffic or relations in the life of a society and a state. The subjects of law consist of a wide law subject and some others are limited or narrow. The subject of law in its wide sense includes the law enforcement process, which involves all subjects in each legal relationship. Anyone who runs a normative rule, or does something, or does not do something, based on the norms of applicable rules means run or enforce the rules of law. The subject of law in a limited or narrow sense means that enforcement of law is only defined as the efforts of certain law enforcement officials to ensure and to safeguard that a rule of law runs as it should. In ensuring the enforcement of the law, where necessary, the law enforcement officials are permitted to use force. ${ }^{6}$

Enforcement as a process is essentially an application of discretion that involves decisions that are not strictly regulated by the rule of law but have an element of personal judgment. ${ }^{7}$ law enforcement is not merely a matter of an enforcement of legislation, although in Indonesia the tendency is in this direction, so the law enforcement is quite popular. It can also be interpreted by the implementation of judge decisions.

Such opinions are actually rather narrow and have weaknesses if the law or judge's decisions interfere peace in the social life. Law enforcement involves many elements in the process. The law enforcement officials are the spearhead of law enforcement within a state.

In a broader sense, law enforcement includes the values of justice contained in the sound of formal rules and values of justice living in a society. However, in a narrow sense, law enforcement only concerns the enforcement of formal and written rules. Therefore, the translation of "law enforcement" into Indonesian term 'Penegakan Hukum' use the broadest sense and also the narrow sense. ${ }^{8}$

The scope of the term 'law enforcement' is immense, since it includes those who directly and indirectly engage in law enforcement. Law enforcement officials are citizens, who have certain rights and obligations to enforce the law (in the sense of delivering the law). ${ }^{9}$ Law enforcement is conducted in order to protect the interests of the people in every state because in people will never be absent with conflict of interest that can always lead to disputes. Hence, law becomes solution, which is expected to fulfill sense of justice for the people. ${ }^{10}$

Theo Hujibers, Filsafat Hukum dalam Lintasan Sejarah, Yogyakarta: Kanisius, 1995, p. 70.

Ahmad Mujahidin, Peradilan Satu Atap di Indonesia, Bandung: PT. Refika Aditama, 2007, p. 10.

Yunan Helmi, "Penegakan Hukum oleh Kepolisian melalui Pendekatan Restorative Justice dalam Sistem Hukum Nasional”, Jurnal Rechts Vinding Media Pembinaan Hukum Nasional, Vol. 2, No. 2, 2013, p. 256.

Andi Hamzah, Hukum Acara Pidana Indonesia, Jakarta: Sinar Grafika, 2005, pp. 48-49.

9 Soerjono Soekanto and Mustafa Abdullah, Sosiologi Hukum dalam Masyarakat, $3^{\text {rd }}$ edition, Jakarta: Rajawali Press, 1987, p. 52.

10 Mahmud Kusuma, Menyelami Semangat Hukum Progresif Terapi Paradigmatik bagi Lemahnya Hukum Indonesia, Yogyakarta: Antony. Lib, 2009, p. 2. 
Law enforcement in concrete terms is the enactment of positive law in practice, as it ought to be obeyed. Therefore, to provide justice in a case means to decide the case by applying the law and finding the law in concreto to maintain and to ensure the compliance of material law by using procedural means established by formal law as the embodiment of the Constitution. The most important thing in law enforcement is actually the enforcement of the law to accomplish the objectives of the law. Law enforcement involves activities to implement and to apply the law and take legal action against any violation or legal irregularity committed by legal subject, to the action of any breach or infringement of legislation, through the judicial process. All of them are parts of legal system that is not separated from each other.

Furthermore, there are three elements of legal system:

1. the structure, namely the entire existing legal institutions and their officials, including, among others, the Police with its police officers, the attorney office with its attorneys, and the courts with the judges;

2. the substance, namely the entire rule of law, legal norms, and legal principles, both written and unwritten, including court decisions; and

3. the legal culture, which is opinions, beliefs, customs, ways of thinking, and ways of acting, both from law enforcement officials and citizens concerning law and various phenomena related to the law. ${ }^{11}$

Furthermore, according to Friedmann, law enforcement is a component of legal system that describes the structural law as a 'driving force' that allows the legal system to work in a society. In other words, Friedmann, as quoted by Abdurrahman, states that it is "the moving parts, so to speak of the machine courts are simple and obvious. $^{12}$

According to Jimly Asshiddiqie, law enforcement officials can be seen as a person or a human with qualities, qualifications, and work culture. The law enforcement officials can also be seen as an institution, body or organization with its own bureaucratic quality. ${ }^{13}$

\section{Factors Affecting Harmony among law enforcement agencies in Law Enforcement Process}

Harmony between law enforcement agencies in this paper refers to the harmony or the harmonization process between the Police institution, with its police officers as the law enforcement officials; the Prosecutor's Office, with its attorneys; the judicial institution with its judges; as well as other institutions like advocates or lawyers. All law enforcement agencies and law enforcement officials must be synergized each other; do not let things that are not expected happen in law enforcement.

Achmad Ali, "Menguak Teori Hukum dan Teori Peradilan: Termasuk Interpretasi Undang-Undang”, Jurnal Yudisial, Vol. 4, No. 1, 2011, p. 102.

12 Abdurrahman, Tebaran Pikiran tentang Studi Hukum dan Masyarakat, Jakarta: Media Sarana Press, 1987, p. 86.

13 Jimly Asshiddiqie, "Menyoal Moral Penegak Hukum", this paper is presented for Lustrum XI Seminar at Faculty of Law, Universitas Gadjah Mada, on February 17, 2006, p. 14. 
Police institution duties have been stipulated in the Law Number 2 of 2002 on the Police of the Republic of Indonesia (Indonesian Police Law). Article 13 of the Indonesian Police Law states that the main duties of the Police of the Republic of Indonesia are: (1) to maintain security and public order; (2) to enforce law; and 3) to provide protection, nurture, and service to the people.

Attorney, under Article 1(1) of the Law Number 16 of 2004 on the Attorney of the Republic of Indonesia (Indonesian Attorney Law), is a functional official that is authorized by law to act as a public prosecutor and executor of a court decision that has obtained permanent legal force as well as other authorities under the law. The duties and authorities of an attorney in a criminal field are regulated in Article 30(1) of the Indonesian Attorney Law. They are, among others: (a) to prosecute; (b) to implement judge decisions of and court decisions that have obtained permanent legal force; (c) to conduct supervision on the implementation of conditional verdict, supervisory verdict, and unconditional verdict; (d) to conduct investigations of certain crimes under the law; and (e) to complete a particular case file and to perform additional checks before the case transferred to a court (which in its implementation is coordinated with the investigator).

Thus, the duties and authorities of attorney shall be the public prosecutor and the executor of the court decision that already have a permanent legal force in the criminal case. For civil cases, the executor of a permanently enforceable court decision is bailiff and registrar presided over by the chief judge. ${ }^{14}$ Furthermore, the public prosecutor could act as disputing party if they are representing the state or the government. It is based on the provision of Article 30(2) of the Indonesian Attorney Law, which reads "In civil and administrative sectors of the state, the attorney office with special powers may act both inside and outside the court for and on behalf of the state or the government."

Article 1(8) of the Law Number 8 of 1981 on the Law of Criminal Procedure (Criminal Procedure Code) states that a judge is a state court official authorized by law to adjudicate. Adjudication is defined as a series of judges' actions to receive, examine, and decide cases based on free, fair, and impartial principles in court in respect of and according to the ordinances of law. A judge has an important position and role of law. Therefore, some values are respected and must be respected by a professional judge in performing duties. The value here is defined as the nature or the quality of something beneficial to human life, both inward and outward..$^{15}$

Law Number 4 of 2004 on Judicial Power (Judicial Power Law of 2004) lists some professional responsibilities of judge. First, judge is required to explore, to follow, and to understand the legal values and sense of justice living in the community. ${ }^{16}$ Second, in considering the severity of crime, judge shall also consider good and evil

see Article 54(2) of the Law Number 48 of 2009 on Judicial Power.

15 Kamil Iskandar, Kode Etik Profesi Hakim dalam Pedoman Perilaku Hakim, Kode Etik Hakim dan Makalah Berkaitan, Jakarta: Mahkamah Agung RI, 2006, p. 3.

16 Article 28(1) of the Law Number 4 of 2004 on Judicial Power (Judicial Power Law of 2004). 
nature of defendant. ${ }^{17}$ Third, judge is required to withdraw from trial if the judge has family ties up to third degree, or even divorced, with the chairman, one of the other members judges, prosecutor, advocate, or registrar. ${ }^{18}$

An advocate or a lawyer is also an institution that has been mandated by law to defend or to advocate or provide legal assistance to the needy with the cost borne by the state or at its own expense.

The form of harmonization, among others, is that the prosecutor that plays a prosecution must be serious and should be fully prepared, so the prosecutor can prove criminal elements committed by perpetrators of criminal acts. Of course, prosecution by the prosecutor is closely related to the materials given by police investigator as the 'basic material' although it must not be perfect but it supports the prosecutor to formulate a good indictment. Therefore, if the prosecution process conducted by prosecutors fails, the failure can be traced from the investigation process conducted by the police whether it is true or not, and also from the incomplete basic materials provided by the investigator. ${ }^{19}$

Jimly Asshiddiqie said that the 1945 Constitution also regulates the authority of each state institution, the mechanism of filling the positions in state institutions, the relationships between state institutions, and the relationship between the state and the citizens containing the guarantee of basic human freedom that must be respected and protected by the state. Therefore, there is a guarantee for the absence of a monopoly of one institution of state power over other state institutions. ${ }^{20}$

Forms of cooperation that can be done by state institutions in order to create a harmonious atmosphere, among them, are as follows:

1. Law enforcement Institutions, for example from all levels of judiciary, attorney, police, lawyer, and penitentiary, should prioritize law enforcement if there is any harm or disturb on people's life. The perpetrator has to deal with the law. The principle of presumption of innocence must still be upheld, as no one can be declared innocent before a judge declares it. This is where it will be proven whether the law is in truth and justice. If the above is not done, then public tends to play to judge themselves. Public can even act anarchically that is very detrimental to the state. All of the mentioned law enforcement agencies are complementary to one another or complement each other, so the purpose of a state to protect the whole Indonesian nation and the whole of Indonesian people can be realized.

2. Educational institutions of all levels from the start of early-childhood, primary, first and upper secondary schools to higher education can include values of justice, legal, and law enforcement. If people from the beginning have been

\footnotetext{
Article 28(2) of the Judicial Power Law of 2004.

18 Article 29(3) of the Judicial Power Law of 2004.

19 Topo Santoso, Polisi dan Jaksa, Keterpaduan atau Pergulatan, Depok: Pusat Studi Peradilan Pidana Indonesia, 2000, p. 71.

20 Jimly Asshiddiqie, Konstitusi \& Konstitusionalisme Indonesia, Jakarta: Sekretariat Jenderal Mahkamah Konstitusi RI, 2006, p. 144.
} 
introduced to obey and enforce the law then they will gradually have a high degree of legal awareness.

3. Legislative bodies and Executive bodies (including financial institutions) should support law enforcement by not interfering it if there is a law to be enforced. In fact, these institutions should provide any data and documents requested if law enforcement officials require it. Here lies harmonization. The House of Representatives (DPR-Dewan Perwakilan Rakyat), for example, should be focused on making rules that can give a fair sense in all matters governed so that people can trust their representatives. The regulation in question is Laws that support the legal official. It should also cover welfare points so that the law official is spared from bribery as well as from other side, which require law, so that law enforcement officials have clear authorities based on laws and regulations. Of course, law must provide justice to the community as a seeker of justice.

In order to improve the law enforcement implementation and efforts for both the community and the law enforcement officials, the government of the Republic of Indonesia has reformed several regulations to improve the existing legal system for the achievement of a just and peaceful society. By the improvement of regulations for law enforcement officials, each party is expected to perform duties and functions responsibly. The implementation is not separated from the supervision of government and society. ${ }^{21}$

People need legal certainty over legal system applicable in their state because law enforcement cannot stand alone without the existence of the legal system. Law enforcement should be accountable, impartial, and not easily intervened so that results can be accountable for the people.

Renewal of legal system is a legal system based in Indonesia. The jurisprudence is expected to absorb the aspirations that live and develop in the community. Laws must be in line with the development of life in community. It should also solve problems through the way of discussion. It is expected that law does not merely put forward imposition as a solution of the existing legal issues. It is because problem solving through courts for small cases will further make the state's cost recovery increase and add new jobs for law enforcement officials. ${ }^{22}$ To create law enforcement with good integrity and humanity and sense of justice, which will encourage better law enforcement toward responsive law, which is in connection with Pancasila values, is the nature of law reform/development. Therefore, the nature of law development or renewal lies not in the formal and outer aspects (such as the formation of new laws, new institutional structures, the increase of justice building/facilities, new mechanism/procedure) but rather on the immaterial aspects of how to build culture and psychological values of law.

Sanyoto, "Penegakan Hukum di Indonesia”, Jurnal Dinamika Hukum, Vol. 8, No. 3, 2008, p. 203.

22 Yadyn (et.al.), "Problematika Penegakan Hukum Indonesia Menuju Hukum yang Responsif Berlandaskan NilaiNilai Pancasila", Jurnal Pasca Unhas, Vol. 1, No. 1, 2012, p. 83. 
The conception of legal state from rechtstaat to the rule of law as it is widely developed in Anglo-Saxon countries is expected to be able to break away from the trappings of formalities and encourage law enforcement to "be creative" and dare to dig up justice values and uphold ethics and morals in society in any legal case settlement. However, one of the problem of law enforcement today is caused by the paradigmatic problem of ambiguity of the orientation of the conception of the rule of law.

Harmony among law enforcement institutions is carried out in the construction of a democratic constitutional state and within the framework of the development of the national legal system. All efforts to structuring and consolidating the national legal system must be done in an atmosphere that is free from political pressure and unconstructive emotions. In this context, the relationship between law enforcement agencies is often an obstacle to law enforcement itself. Therefore, it is necessary to build a system that integrates relationships between legal institutions to become more harmonious.

Factors affecting harmonization among law enforcement agencies in law enforcement activities are as follows:

\section{Factors of Laws or Regulations}

The factors appear due to:

1. the principles of the coming into effect of a legislation are not included in the regulation;

2. implementation rules that are needed to enforce legislation do not exist yet; and

3. lack of clarity in the meaning of words within the legislation will result in confusion in its interpretation and application. ${ }^{23}$

The problem of law enforcement in Indonesia is very difficult to trace, such as finding the cover of the base or the end of a circle, thus making the crime sovereign in the world of law as well as the Judiciary in Indonesia. The issue of law enforcement in Indonesia often begins in the world of justice, judicial mafia is often a major factor in law enforcement issues, as judicial mafias are systemic and pervade law enforcement.

Mahfud MD in his book titled "Politik Hukum di Indonesia" says: ${ }^{24}$

"Mereka heran ketika melihat bahwa hukum tidak selalu dapat dilihat sebagai penjamin kepastian hukum, penegak hak-hak masyarakat, atau penjamin keadilan. Banyak sekali peraturan hukum yang tumpul, tidak mempan memotong kesewenang-wenangan, tidak mampu menegakkan keadilan dan tidak dapat menampilkan dirinya sebagai pedoman yang harus diikuti dalam menyelesaikan berbagai kasus yang seharusnya bisa dijawab oleh hukum. Bahkan banyak produk

23 Soejono Soekanto, Faktor-Faktor yang Mempengaruhi Penegakan Hukum, Op.cit., p. 11-18.

24 Mahfud MD, Politik Hukum di Indonesia, Jakarta: Penerbit LP3ES, 2001, p. 1. 
hukum yang lebih banyak diwarnai oleh kepentingan-kepentingan politik pemegang kekuasaan dominan".

[They are surprised to see that law cannot always be seen as the guarantor of legal certainty, the enforcers of the rights of the people, or the guarantor of justice. There are lots of legal rules that are blunt, unable to cut arbitrariness, unable to uphold justice, and cannot present themselves as guidelines to be followed in resolving cases that the law should be able to answer. In fact, many of the products of law are marked by political interests of the dominant power holders]

The basis of law enforcement that can answer the demands of society must be responsive law, otherwise the law will lose its spirit. Moral and justice is the spirit of law. Law reform should look back on the living, growing, and developing order of morality in society. The voices of people from below must be recited by formulating various policies outlined in the products of law. ${ }^{25}$

\section{Factors of Law Enforcement Agencies and Law Enforcement}

Issues of law enforcement include:

1. negative views of citizens against law enforcement because they have been in contact with law enforcement;

2. the existence of violence and coercion from law enforcement officials so that people feel afraid;

3. the existence of interventions to personal interests based on the experiences of citizens who have ever dealt with law enforcement; and

4. bad influence of law enforcement officials.

To answer the problems of law enforcement officials, of course, things that are considered bad by people should be avoided, for example by not intervening personal interests, trying hard to avoid violence and coercion in law enforcement. Law enforcement officials should always do things in accordance with rules so that negative stigma of law enforcement officials can be gradually eliminated. Similarly, about the influence of superiors that can give a bad influence for law enforcement officials, law enforcement subordinates must also have principles to obey the rules. If they violate rules, even if it is based on the superior order, law enforcement will not be realized.

A law enforcement official has a position and a role; the position can be high or low. The role of law enforcement officials here is closely related to discretion (the need for discretion in the absence of regulation, the delays in regulation, the lack of costs, the presence of individual cases that need special handling). In carrying out the role, law enforcement officials must know their rights and obligations. Right is the authority to act; obligation is the burden or the task carried out. If the role

25 M. Husni, "Moral dan Keadilan Sebagai Landasan Penegakan Hukum”, Jurnal Equality Fakultas Hukum Universitas Sumatera Utara, Vol. 11, No. 1, 2006, p. 3. 
performed is not in accordance with role or position there will be conflict. ${ }^{26}$

Law enforcement officials include the notion of law enforcement agencies and law enforcement personnel. In a narrow sense, the law enforcement officials involve in law enforcement process, starting from witnesses, police, legal counsel, prosecutors, judges, and prison officers. Each official is a part of parties concerned with their duties or roles related to reporting or complaint, analysis, investigation, prosecution, verification, verdict, and sanction, as well as reconciliation of the convicted person.

In the process of working of the law enforcement officials, there are three important elements that influence:

1. a regulatory instrument that supports both institutional performance and those governing legal material as the standard of work, both material law and procedural law;

2. work culture associated with the officials, including welfare of its official; and systemic law enforcement efforts shall take these aspects into account simultaneously, so that the process of law enforcement and justice itself can internally be manifested; and

3. law enforcement institutions and their various supporting facilities and infrastructure and their institutional working mechanism.

The results of a research show that the legal deterioration in terms of legal substance covers the entire rule of law, legal norms and legal principles, both written and unwritten are outdated and are the product of the Dutch colonial heritage. Therefore, the law is felt less aspirational in absorbing the expectations of the people of Indonesia and are not in line with the values of Pancasila. Based on the analysis, the legal deterioration of the legal culture aspect shows that bribery practices are a habit of law enforcement in Indonesia. There are $87 \%$ of respondents from three sites stated that law enforcement officials in Indonesia have not been clean from bribery. The analysis of the overall result of the research in the form of legal structure to law enforcement officials puts $70 \%$ of the distrust of the society on law enforcement officials in Indonesia. It is caused by various factors such as the integrity of law enforcement officials, the low level of performance, and values of Pancasila in the implementation of daily tasks. ${ }^{27}$

The public, for example, often hear the back and forth of case file to more than three times from the prosecutor to the police. This long journey of court file is sometimes used by various parties with various intentions by making a request for permission to escape, to eliminate evidence, to transfer wealth that can be the results of corruption and hide it. Prosecutor and police should understand and improve to reform in a good coordination. If such bad coordination continues, it will reduce the image of law enforcement agencies and also public confidence.

26 Soerjono Soekanto, Faktor-Faktor yang Mempengaruhi Penegakan Hukum, Op.cit., pp. 19-36.

27 Yadyn, (et.al), Op.cit., p. 81. 


\section{Factors of Community}

Communities can also influence harmony among law enforcement agencies. In this case, for example, is the compliance of public on a law. Knowledge of community on law also affects compliance. Law is understood by the people of Indonesia as:

1. a norm or rule (a benchmark in behaving);

2. the rule of law;

3. officer or official;

4. the decision of the ruler or power holder;

5. a regular and unique behavior;

6. a value chain;

7. art;

8. science;

9. discipline; and

10. a process of governance.

The law as officer or official is the most widely understood. Therefore, law is affected by law enforcement official behavior. Therefore, they want officials like police officer can resolve case immediately. ${ }^{28}$

Not all legislations can create changes in society in accordance with what the purposes of the legislations. Through the method of law as a tool of social engineering, the goal pioneered by agent of change can be achieved. However, for the "law as a tool of social engineering" method can be used effectively, attention should be paid to the four main principles. Adam Podgorecki describes the four main principles as follows: ${ }^{29}$

1. Mastering well the situation at hand.

2. Verifying hypotheses such as whether a method that is expected to be used in the end will indeed lead to the desired goal.

3. Making an analysis of the existing assessments and place them in a hierarchical order. The analysis in this case also includes assumptions about whether the method to be used will not lead to an adverse effect.

4. Measurement of the effect of existing legislation.

Concerning the concept of law as a tool of social engineering, if a ruler does not give priority to morality in the creation of law, the law will be used as a tool of crime. Roni Rahman Nitibaskara, once expresses that in the development of legal practice, it turns out that often the law is abused to commit a crime. ${ }^{30}$

\section{Factors of Culture}

Another thing that affects harmonization among law enforcement agencies is the cultural factors. Culture is the value that underlies the applicable law. Values are abstract conceptions of what are considered good so that the values are embraced

Soejono Soekanto, Faktor-Faktor yang Mempengaruhi Penegakan Hukum, Op.cit., pp. 45-58.

C.J.M Schuyt, Rechts Sosoilogie een Terreinverkening, Rotterdam: Rotterdam Universitaire Pres, 1971, p. 54.

Roni Rahman Nitibaskara, Tegakan Hukum Gunakan Hukum, Jakarta: Penerbit Buku Kompas, 2006, p. 60. 
and what are considered bad then the values are avoided. Couples of values that play a role in the law include physical and spiritual values, order and tranquility values, and conservative and innovative values.

By the physical and spiritual values, sanctions and consciousness are interrelated, but there is a need for in-depth research on their relationship. The order values are usually referred as attachment or discipline while the tranquility values are freedom. From the conservative values, there is an assumption that law only follows changes and maintains the "status quo". It also serves as a means of change and creates new things. ${ }^{31}$

All this time, the culture embraced by law enforcement agencies is the culture of sectoral ego and the feeling of being the most important. It often triggers conflicts of interests in the law enforcement process. Harmony among law enforcement officials in law enforcement process should be a culture to avoid negative things because of common prejudice related to law practice. The Culture of laws that exist in law enforcement process can also include variety of challenges and risks of temptation in the investigation stage that are so complex. They cover the scope of work, power possessed, the authority possessed, and so forth. Issues in the investigation phase include case negotiation, extortion, status negotiation, suspect discharge, and embezzlement of cases. The issues in the prosecution phase are also very complex, such as in the case of negotiation of the indictment chapter, the status negotiation by making unclear indictment (obscuur libel) so that it is acquitted. In addition, there are also demand for bribery, determination of judges, and negotiating decisions.

Legal ethic and legal science/education reform include the renewal of the immaterial aspects of the law, namely reformation of legal culture, legal ethics/ morals, law enforcement officials, and legal science/education. They can be reformed to implement the ideal law (ius constituendum). The current deterioration of law enforcement officials is preceded by a decline in their moral decadence. Their money-oriented concept should have been changed to the mindset of "Service Oriented without Money". It requires legal reform not only in terms of reform of the law or its legal substance but also the legal structure reform. ${ }^{32}$

\section{Efforts to Overcome Factors Affecting Harmony among Law Enforcement Institutions}

According to Sofyan Lubis, there are some necessary steps to build accountable law enforcement as follows:

1. There is a need to refine, to update, and to complete existing laws and legislation.

2. Since nowadays there are only a few of law enforcement officials that do not understand the idealism of law that is enforced, so the quality of human

Soejono Soekanto, Loc.cit., pp. 59-67.

32 Barda Nawawi Arief, Masalah Penegakan Hukum dan Kebijakan Hukum Pidana dalam Penanggulangan Kejahatan, Jakarta: Kencana Pranada Media Grup, 2010, p. 6. 
resources of law enforcement needs to be improved in terms of morality and intellectuality.

3. There should be a standardization and welfare enhancement for law enforcement officials who are paid like judges, prosecutors and police officer. So that their professionalism as a main actors of law enforcement in Indonesia can be enhanced and they are also expected to focus more to the purpose of the law itself.

4. The law enforcement elements consisting of judge, advocate, attorney, and police are expected to have goodwill that can lead to commitment together. It should be initiated and started by law enforcement officials, as well as all levels of society. The commitment, in turn, will also lead to legal culture in this country.

5. An independent agency authorized to recommend sanctions for law enforcement agencies who violate established enforcement processes should be established. The members may cover qualified public elements (non-active judges, active prosecutors, and active police officer) aimed at overseeing the law enforcement process. ${ }^{33}$

6. The role of printed media (press) and electronic media (TV and Radio), as well as NGO groups, is urgently needed to do intensive socialization of law and legislation to the wider community as a consequence of the legal principle which says that "Every society is considered to know the law". It is because they know and pay attention in doing "advocacy", disseminating information to society and government and related parties, in order to build legal behavior and culture. ${ }^{34}$

Establishing an accountable law enforcement system based on the proposals and the steps above certainly cannot go in a good manner because law enforcement is part of the legal system of governance and it will not succeed without the full support of a clean government.

Therefore, in building an accountable law enforcement system, there should be systematic and organized efforts in continuous law socialization to the community so that law enforcement officials along with all components of society can implement accountable law enforcement. In this case, people shall be informed about the criteria/measures used as the basis for assessing an accountable law enforcement accountability. Accountable law enforcement is the foundation and an evidence of Indonesia is based on rule of law (rechtsstaat). ${ }^{35}$

Factors mentioned above greatly affect the harmony among law enforcement agencies in Indonesia. The law enforcement can be done properly and correctly if these factors can be maintained. For example, the solution for legal factors is the enactment of principles of legislation, immediately applying necessary

33 see Article 9(1) and (2) of the Judicial Authority Law of 2004, Article 17 jo. Article 3(2) and (3) jo. Article 18(1) and (4) of Law Number 39 of 1999 on Human Rights.

34 Sofyan Lubis, "Tanggung Jawab Penegakan Hukum di Indonesia", http://artikel.kantorhukum-lhs.com/ tanggung-jawab-penegakan-hukum-indonesia, accessed on September 2017.

35 Ibid. 
implementation of rules and regulations. The words in the legislation should be clear, not to be interpreted in various ways.

The solution to the factors of law enforcement officials and law enforcement agencies is that every law enforcer should be able to exercise their rights and obligations. Therefore, when a law enforcer performs his/her role according to the assigned task there will be no conflict in the community. There should be no sectoral ego so there is no presumption that an institution is more important than other institutions. All must build harmonization and synergy so that the desired goals can be realized.

Furthermore, for factors of community that need to be done is to give a good understanding to the public about legal knowledge so that they do not misunderstand and the judgment of society to the law can be correct. A good understanding will make the community give an objective assessment of law enforcement, they will obey the law with full awareness, and it makes the law enforceable. Socialization must be done massively because many people do not understand properly the legal process and examination and anything related to obtaining justice through the judiciary so that people really understand and will not violate moral values by performing bribery, fraud, coercion, and others.

For factors of culture, a good society culture must remain accustomed so that law enforcement can be done well. If the culture of society is not good then it is difficult for compliance and law enforcement can be postponed and delayed. A good culture is also expected to be exemplified by state and law enforcement officials. If the law enforcement officials can be examples for society, then the society will be reluctant to do crimes.

Several issues concerning law enforcement, of course, cannot be separated from the fact that the functioning of the law is highly dependent on a harmonious relationship among the laws, law enforcement officials, facilities, and the society. Limitation on an element may affect the whole system to be negative. ${ }^{36}$

The above ideas have been proven by some results of researches conducted on law enforcement officials. Based on the results, the deterioration of law enforcement in Indonesia lies in the integrity factor of law enforcement officials, unresponsive law rules, and the application of Pancasila values, especially the value of deliberation to consensus, and the value of justice in law enforcement by law enforcement officials. All of them cause mistrust of the community against law enforcement in Indonesia. The result of the research shows that the level of public confidence in law enforcement is influenced greatly by the circumstances or situation of a region. If in an area the law enforcement is good, the level of public trust in the area is also good. On the contrary, if the law enforcement is bad then it will also effect the law. ${ }^{37}$

Soekanto and Mustafa Abdullah, Sosiologi Hukum dalam Masyarakat, Op.cit., p. 20.

37 Yadyn, (et.al.), Op.cit., p. 84. 


\section{E. Conclusion}

Factors affecting harmony among law enforcement agencies in Indonesia are: (a) laws or regulations; (b) law enforcement agencies and law enforcement; (c) community; and (d) culture.

Harmony among law enforcement agencies must be implemented because it will create an atmosphere of mutual support and complementary that will create law enforcement to be in accordance with the objectives of law and the goals of the state of the Republic of Indonesia. This harmonization is expected to be built within all levels of law enforcement agencies. If all levels of the law enforcement agencies can be in harmony, the legal certainty, justice, and expediency expected in law enforcement will be achieved.

Efforts that can be done to manage the factors is to seek a variety of regulations from both central and local so that harmonization process can be realized according to existing rules. The principles of legislation must be implemented. The necessary implementation of rules must be performed immediately. The words in the legislation should be clear, not to be interpreted in various ways that lead to confusion in its application. For the factor of law enforcement agencies and law enforcement officials, each law enforcement agency must be able to exercise its rights and obligations, so they can act in accordance with the task given and to avoid conflict within the community. This removal of sectoral ego is also needed so there is no presumption that one of the institutions is more important than other institutions. All must perform harmonization and synergy so that the desired goals can be achieved. For factors of community, public needs to be educated so that they do not misunderstand. It is expected that the good judgment of society against the law can be correct. For factors of culture, the society must remain accustomed to obey and to support law enforcement. If the culture of society is not good, then it will be difficult for compliance and the law enforcement will be delayed and postponed. A good culture is also expected to be exemplified by state and law enforcement officials. If they can be an example for the community, the harmonization among law enforcement agencies can be achieved, the legal objectives can be achieved, and the law in Indonesia can be upheld.

\section{References}

\section{Books}

Abdurrahman, Tebaran Pikiran tentang Studi Hukum dan Masyarakat, Media Sarana Press, Jakarta, 1987.

Ahmad Mujahidin, Peradilan Satu Atap di Indonesia, PT. Refika Aditama, Bandung, 2007.

Andi Hamzah, Hukum Acara Pidana Indonesia, Sinar Grafika, Jakarta, 2005.

Barda Nawawi Arief, Masalah Penegakan Hukum dan Kebijakan Hukum Pidana dalam Penanggulangan Kejahatan, Kencana Pranada Media Grup, Jakarta, 2010. 
Jimly Asshiddiqie, Konstitusi \& Konstitusionalisme Indonesia, Sekretariat Jenderal Mahkamah Konstitusi RI, Jakarta, 2006.

Kamil Iskandar, Kode Etik Profesi Hakim dalam Pedoman Perilaku Hakim, Kode Etik Hakim dan Makalah Berkaitan, Mahkamah Agung RI, Jakarta, 2006.

Mahfud MD, Politik Hukum di Indonesia, Penerbit LP3ES, Jakarta, 2001.

Mahmud Kusuma, Menyelami Semangat Hukum Progresif Terapi Paradigmatik bagi Lemahnya Hukum Indonesia, Antony. Lib, Yogyakarta, 2009.

Roni Rahman Nitibaskara, Tegakan Hukum Gunakan Hukum, Penerbit Buku Kompas, Jakarta, 2006.

Satjipto Rahardjo, Masalah Penegakan Hukum, Bandung, Sinar Baru, 1983.

Schuyt, C.J.M, Rechts Sosoilogie een Terreinverkening, Rotterdam Universitaire Pres, Rotterdam, 1971.

Soerjono Soekanto and Mustafa Abdullah, Sosiologi Hukum dalam Masyarakat, $3^{\text {rd }}$ edition, Rajawali Press, Jakarta, 1987.

Soerjono Soekanto, Faktor-Faktor yang Mempengaruhi Penegakan Hukum, Rajawali Pers, Jakarta, 2014.

Taufiqurrahman Shahuri, Tafsir Konstitusi Berbagai Aspek Hukum, Kerncana, Jakarta, 2011.

Theo Hujibers, Filsafat Hukum dalam Lintasan Sejarah, Kanisius, Yogyakarta, 1995.

Topo Santoso, Polisi dan Jaksa, Keterpaduan atau Pergulatan, Pusat Studi Peradilan Pidana Indonesia, Depok, 2000.

\section{Other Documents}

Achmad Ali, "Menguak Teori Hukum dan Teori Peradilan: Termasuk Interpretasi Undang-Undang", Jurnal Yudisial, Vol. 4, No. 1, 2011.

Cambridge English Dictionary, 'harmony', https://dictionary.cambridge.org/ dictionary/english/harmony, accessed on September 2017.

Jimly Asshiddiqie, "Menyoal Moral Penegak Hukum", this paper is presented for Lustrum XI Seminar at Faculty of Law, Universitas Gadjah Mada, on February 17, 2006.

M. Husni, "Moral dan Keadilan Sebagai Landasan Penegakan Hukum”, Jurnal Equality Fakultas Hukum Universitas Sumatera Utara, Vol. 11, No. 1, 2006.

Rif'ah Roihanah, "Penegakan Hukum di Indonesia: Harapan dan Kenyataan", Justitia Islamica, Vol. 12, No. 1, 2015.

Sanyoto, "Penegakan Hukum di Indonesia", Jurnal Dinamika Hukum, Vol. 8, No. 3, 2008.

Sofyan Lubis, "Tanggung Jawab Penegakan Hukum di Indonesia", http://artikel. kantorhukum-lhs.com/tanggung-jawab-penegakan-hukum-indonesia, accessed on September 2017. 
Yadyn (et.al.), "Problematika Penegakan Hukum Indonesia Menuju Hukum yang Responsif Berlandaskan Nilai-Nilai Pancasila", Jurnal Pasca Unhas, Vol. 1, No. 1, 2012.

Yunan Helmi, "Penegakan Hukum oleh Kepolisian melalui Pendekatan Restorative Justice dalam Sistem Hukum Nasional", Jurnal Rechts Vinding Media Pembinaan Hukum Nasional, Vol. 2, No. 2, 2013.

\section{Legal Documents}

The 1945 Constitution of the Republic of Indonesia.

Law Number 8 of 1981 on the Law of Criminal Procedure.

Law Number 39 of 1999 on Human Rights.

Law Number 2 of 2002 on the Police of the Republic of Indonesia.

Law Number 4 of 2004 on Judicial Power.

Law Number 16 of 2004 on the Attorney of the Republic of Indonesia.

Law Number 48 of 2009 on Judicial Power. 